Transactions of the Royal Society of Edinburgh: Earth

Sciences

http://journals.cambridge.org/TRE

Additional services for Transactions of the Royal Society of Edinburgh: Earth Sciences:

Email alerts: $\underline{\text { Click here }}$

Subscriptions: $\underline{\text { Click here }}$

Commercial reprints: $\underline{\text { Click here }}$

Terms of use : $\underline{\text { Click here }}$

\title{
Embryophytic sporophytes in the Rhynie and Windyfield cherts
}

\section{Dianne Edwards}

Transactions of the Royal Society of Edinburgh: Earth Sciences / Volume 94 / Issue 04 / December 2003, pp 397 - 410

DOI: 10.1017/S0263593300000778, Published online: 26 July 2007

Link to this article: http://journals.cambridge.org/abstract_S0263593300000778

How to cite this article:

Dianne Edwards (2003). Embryophytic sporophytes in the Rhynie and Windyfield cherts. Transactions of the Royal Society of Edinburgh: Earth Sciences, 94, pp 397-410 doi:10.1017/S0263593300000778

Request Permissions : $\underline{\text { Click here }}$ 


\title{
Embryophytic sporophytes in the Rhynie and Windyfield cherts
}

\author{
Dianne Edwards
}

\begin{abstract}
Brief descriptions and comments on relationships are given for the seven embryophytic sporophytes in the cherts at Rhynie, Aberdeenshire, Scotland. They are Rhynia gwynnevaughanii Kidston \& Lang, Aglaophyton major D. S. Edwards, Horneophyton lignieri Barghoorn \& Darrah, Asteroxylon mackiei Kidston \& Lang, Nothia aphylla Lyon ex Høeg, Trichopherophyton teuchansii Lyon \& Edwards and Ventarura lyonii Powell, Edwards \& Trewin. The superb preservation of the silica permineralisations produced in the hot spring environment provides remarkable insights into the anatomy of early land plants which are not available from compression fossils and other modes of permineralisation. They include soft tissues, such as those surrounding stomata, rhizoids, apical and lateral meristems, and diversity in conducting cells, with inferences for palaeoecophysiology, including water use efficiency, transport and absorption, and for growth processes and patterns.
\end{abstract}

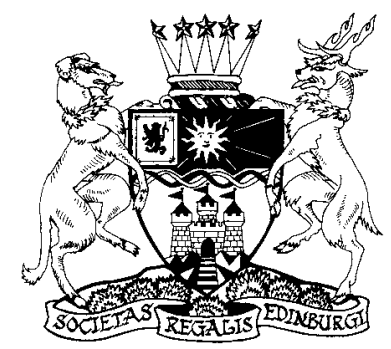

KEY WORDS: Exceptional preservation, Lycopsida, meristems, palaeoecophysiology, Rhyniopsida, silicification, substomatal chamber, water absorption, xylem, Zosterophyllopsida.

The higher plant taxa in the Rhynie chert, Aberdeenshire, Scotland, although contributing relatively little to Lower Devonian numerical diversity, surely compensate in their contribution to our understanding of the anatomy of early land plants and their roles in early terrestrial ecosystems. The present author's brief is to review current knowledge on the sporophytes of the seven embryophytic taxa-five of which were known to Kidston \& Lang - and to summarise, somewhat idiosyncratically, the unique insights afforded by the superb preservation of the silica permineralisations. These have been revealed by the meticulous descriptions of thousands of laboriously prepared peels and sections which show anatomical information far in excess of that derived from more conventional compression and permineralised fossils.

\section{Descriptions of sporophytes}

\subsection{Rhynia gwynne-vaughanii Kidston \& Lang (Figs}

1b, b', 2a-c, m, o, 3a, j, m)

1.1.1. Descriptions. Rhynia gwynne-vaughanii was originally reconstructed by Kidston \& Lang (1921) as a rather simple vascular plant, c. $20 \mathrm{~cm}$ high, with smooth bifurcating axes bearing numerous hemispherical projections, adventitious branches, terminal sporangia and a limited horizontal rhizome (possibly belonging to Aglaophyton) (Kidston \& Lang 1917, 1921). Its xylem was a terete central bundle of tracheids with broad annular or helical thickenings (Fig. 2a). In older assumed decaying examples, these thickenings disappear and the xylem is darkly stained. In contrast, some of the lateral buds and short adventitious branches, possible agents of vegetative propagation, lacked vascularisation when shed, their positions marked by a patch of darkened tissue, while in more developed adventitious branches, there was no continuity of tracheids between those in the branches and those in the axes bearing them. The hemisperical projections are never vascularised. They were produced in maturing axes by deepseated cortical cell divisions with some additional compensating epidermal divisions. Stomata are present on all except the most proximal (basal) projections, which bear rhizoids. D. S.
Edwards' (1980) reconstruction of the plant shows more overall complexity, particularly in the abundance of adventitious branches - dichotomous branching being comparatively rare. He also provided detailed anatomical information on changes in the xylem as it passed through a zone of darkened cells before it terminated in a pad of tissue at the base of the sporangium (Fig. 2b). He speculated that, after sporangial abscission through the darkened zone, growth was resumed by a more proximal adventitious branch, a form of overtopping. Data on extraxylary tissues are given in D. Edwards, Kerp \& Hass (1998). Homosporous eusporangia, normally found isolated, were fusiform, $<5.1 \mathrm{~mm}$ long and contained spores, $<53 \mu$ m diameter, with granular ornamentation. Bhutta (1969) had described the sporangial wall in detail, and in contrast to Aglaophyton had noticed a lack of stomata. D. S. Edwards' reconstruction lacked a basal region because he and others had failed to find convincing evidence. Bhutta (1969) had illustrated two possible examples, one with clusters of rhizoids on the lower surface of a short presumed rhizome, bearing the bases of a number of upwardly directed axes, the latter lacking any hemispherical projections, although in another example, rhizoids were confined to the lower surface of the latter alongside an area with a more extensive rhizoidal region. The specimen illustrated here (Fig. 2c) was identified as R. gwynne-vaughanii by A. G. Lyon.

1.1.2. Relationships. Rhynia gwynne-vaughanii was originally placed with $R$. major, Hornea and Psilophyton princeps (in part) in the Rhyniaceae in the Psilophytales (Kidston \& Lang 1920a). Banks $(1968,1975)$ made the genus Rhynia the type of his new subdivision, the Rhyniophytina, and included it in the Rhyniaceae, together with a number of taxa showing terminal sporangia, dichotomous branching and probably terete centrarch xylem strands. Edwards \& Edwards (1986) reduced the number to three (Rhynia plus Taeniocrada decheniana and Renalia in part), whilst Banks (1992) united the eponymous taxon with Uskiella spargens and Cooksonia. In the meantime, the discovery of S-type tracheids in $R$. gwynnevaughanii, Stockmansella and Huvenia (Kenrick \& Crane 1991; Kenrick et al. 1991) which also share fusiform sporangia characterised by an abscission or isolation layer in their 
pedicels, led initially to their inclusion in the Rhyniaceae (Kenrick \& Crane 1991), whilst in a further cladistic analysis (Kenrick \& Crane 1997), the three taxa were united in an extinct clade (named the Rhyniopsida) and considered a sister group to all other vascular plants (Hass \& Remy 1991).

The description of the fertile gametophytes of $R$. gwynnevaughanii (Kerp et al. 2004) finally brings to an end early speculation that the taxon, as originally described, was a gametophyte (see discussion in D. S. Edwards 1980).

\subsection{Aglaophyton major Edwards $=$ Rhynia major}

\section{Kidston \& Lang Figs 1a, a', 2d, e, j, k, n, 3h, i)}

1.2.1. Description. Kidston \& Lang (1917) included both sterile and fertile parts of Aglaophyton in their original description of $R$. gwynne-vaughanii, but subsequently (1920a) erected a new species of Rhynia, to accommodate them. Rhynia major was conceived as larger and simpler than $R$. gwynne-vaughanii (lacking hemispherical projections or adventitious branches) with homosporous terminal eusporangia reaching a length of $12 \mathrm{~mm}$. Kidston \& Lang (1920a) described the central xylem strand as comprising narrower central tracheids and wider peripheral ones (Fig. 2d), and despite their apparent perfection of preservation, could find no indications of tracheidal thickenings (Fig. 2e). They believed that the uniform appearance resulted from decay of the original wall.

Further vegetative anatomical data (phloem with putative sieve areas) were obtained by Satterthwait \& Schopf (1972), Bhutta (1973a), Remy \& Remy (1977), Lemoigne \& Zdebska (1980), Remy \& Hass (1996) and D. Edwards, Kerp \& Hass (1998). D. S. Edwards (1986) produced a new reconstruction based on serial sections characterised by a basal rhizomatous system in which patches of rhizoids occur on bulges on the lower surfaces of undulating (U-shaped) rhizomes presumably where they had come in contact with the substrate. Details of the vasculature of these rhizoidal bulges, and far more complex growth patterns involving arrested apices, were given in Remy \& Hass (1996, pp. 182-9).

Some subsequent studies have concentrated on sporangia and dehiscence. Thus, Remy (1978) in describing the anatomy of the sporangium wall emphasised the detailed distribution of thickenings in the majority of epidermal cells (cohesion cells) with outer periclinal walls being the thinnest walls and the anticlinal walls, the thickest. Contraction of these cells is purported to have resulted in longitudinal splitting, although whether or not this was along a predetermined line with modified tissue could not be determined. Remy (1978) described a longitudinal hinge-zone of rectangular to square cells opposite the slit, and considered the spiralling in the walls to be a consequence of dehiscence. In contrast, Kerp and Hass (pers. comm. 2003) described one to several spirally aligned longitudinal slits with the tip remaining intact. Remy \& Hass (1996) suggested that spores $(<64 \mu \mathrm{m}$ in diameter) were shed in tetrads and in clumps, the latter possibly indicative of passive dispersal.

1.2.2. Relationships. Originally named Rhynia major, it was placed with the type species in the Rhyniaceae of the Psilophytales (Kidston \& Lang 1920a). D. S. Edwards (1986) had emphasised the lack of conventional tracheidal thickenings in the xylem (see Hébant 1977), and considered this difference along with sporangial abscission in $R$. gwynnevaughanii sufficient to merit the erection of a new genus Aglaophyton. Aglaophyton then appeared to have a far simpler growth pattern compared with $R$. gwynne-vaughanii, at least in its dichotomously branching aerial axes (but for complexity in basal parts, see Remy \& Hass 1996). Similarities in the vesiculate nature of some xylem elements (Fig. 3i, j) between Aglaophyton and Rhynia (Remy \& Hass 1996; D. Edwards
2003) would seem to narrow the differences between the two genera, and therefore, possibly invalidate the necessity for generic changes. It certainly casts doubt on the placement of Aglaophyton outside the Tracheophyta, as had been contemplated in perceived similarities of its water-conducting cells with those of bryophytes (Hébant 1973; D. S. Edwards 1986). In Kenrick \& Crane's (1997) cladistic analysis, Aglaophyton is resolved along with Horneophyton as a basal polysporangiate, the critical character being the smooth-walled, waterconducting cells (but see below for tracheidal thickenings in Horneophyton).

\subsection{Horneophyton lignieri Barghoorn \& Darrah (= Hornea lignieri Kidston \& Lang) (Figs 1d, d', 2f, g, 1)}

1.3.1. Description. The plant was about $20 \mathrm{~cm}$ high, with aerial stems up to $2 \mathrm{~mm}$ in diameter showing dichotomous branching that increased in frequency distally. The basal region comprised a 'lobed tuberous rhizome' from which arose a number of aerial stems. Kidston \& Lang (1920a) compared the basal structures with the protocorms of certain Lycopodium species. They lacked tracheids and bore bands of very long unicellular rhizoids on the lower surfaces. Although essentially parenchymatous, they contained darkened cells in a bell-shaped configuration, from the upper surface of which strands extended into the aerial axes. Frey, Hilger \& Hofmann (1996) suggested that the tubers were gametophytic, based on a single section showing a possible gametophyte/sporophyte junction, the latter represented by the base of an aerial axis. Although often poorly preserved, the terete strands in the latter show unequivocal narrow interconnected annular or spiral thickenings, with the smaller elements situated centrally where breakdown frequently occurred. The tracheids were surrounded by elongate, thin-walled cells interpreted as phloem. Details of extra vascular tissues are given in Hass (1991) and Edwards et al. (1998). Particularly striking were the exceedingly long $(<1000 \mu \mathrm{m})$ and wide epidermal cells (Fig. 2f, 1) surrounding occasional stomata and cortical cells with pronounced intercellular spaces resembling palisade mesophyll, but with long axes directed distally at an angle to the surface. Similarly orientated photosynthesising cells occur in stems and needle-like leaves of certain angiosperms (Meyer 1962). Fewer intercellular spaces are seen between the elongate and overlapping inner cortical cells.

The terminal homosporous eusporangia are unusual in that they were columellate and branched with a single continuous sporangial cavity. Cells of the columella resemble those of the phloem. While Kidston \& Lang (1920a) recorded mainly single and some branched examples, later authors described two, four or even five lobed sporangia (Bhutta 1973b; Eggert 1974; El-Saadawy \& Lacey 1979). Lobes had truncated tips which could be slightly convex, concave or smooth, but all showed epidermal cells at the summit with outer and anticlinal walls thickened. Spore dispersal mechanisms remain conjectural. Kidston \& Lang (1920a) thought that the sporangia were indehiscent, but others have described the existence of one or more slits (Bhutta 1973b) or an apical pore (Eggert 1974). El-Saadawy \& Lacey (1979) suggested that such a pore developed when cells in the central area became displaced and the surrounding cuticle curved inwards. Hass (1991) recorded splitting along the middle lamellae of these central cells. El-Saadawy \& Lacey (1979) also described emergences on the sporangia, each terminating in a single stoma whose guard cells were relatively thinly cuticularised compared with the remaining epidermal cells. Similar structures, called rounded elevations, were described by Hass (1991), but were outnumbered by 'secretory organs' occurring in the flatter areas 
(Fig. 2g). These were groups of irregularly shaped cells radiating from a central pore filled with darkly staining material. Similar structures also occurred on the aerial stems.

Spores were of the same size (c. $57 \mu \mathrm{m}$ diameter) and showed a number of surface features, but recent investigations have suggested that they bore proximal ridges, and thus, belong to the dispersed taxon Emphanisporites (Edward \& Richardson 2000; Wellman et al. 2004).

1.3.2. Relationships. Hornea was placed with Rhynia in the Rhyniaceae (Psilophytales) by Kidston \& Lang (1920a), and broad comparisons were made with bryophytes in its possession of a columella and with the Lower Devonian fossil, Sporogonites exuberans Halle (1916). Since subsequent investigations were inconclusive on the presence of a columella in the latter (Halle 1936), Horneophyton remains the only Lower Devonian vascular plant with this structure. It was classified in the Rhyniaceae in the Rhyniophytina by Banks (1975), an assignation later questioned by Edwards \& Edwards (1986) on its uniquely and prominently branching sporangia (El-Saadawy \& Lacey 1979). Based on an assumption that Horneophyton lacked tracheidal thickenings, in Kenrick and Crane's (1997) cladistical analysis, Horneophyton is resolved as a protracheophyte (this grade also including Aglaophyton) that is basal to all other polysporangiates. It was placed in its own division, Horneophytopsida, tentatively along with Caia and Tortilicaulis, compression fossils for which no vascular data are known, but which sometimes show bifurcating sporangia (Kenrick \& Crane 1997).

\subsection{Asteroxylon mackiei Kidston \& Lang (Figs 1e, e', $\left.\mathrm{e}^{2}, 3 \mathrm{~b}, \mathrm{c}\right)$}

1.4.1. Description. Kidston \& Lang's (1921) reconstruction shows upright leafy shoots arising from horizontal smooth axes which themselves produce downwardly directed dichotomously branching axes, the leafless system interpreted as rhizomes not roots. Kidston \& Lang (1920b) acknowledged that concepts of the whole plant were based not on a single specimen, but on a series showing a concatenation of characters, and advocated that 'caution is therefore necessary in mentally reconstructing the plant as it grew'. There were also similarities in the secondary thickenings (close-set annular or helical) of the tracheids in all fragments. A similar reconstruction with less branching in aerial axes and unbranched rhizome was published by Chaloner \& MacDonald (1980). In contrast, an unpublished reconstruction in Bhutta's (1969) thesis was based on a series of sections from one individual. It shows an upright main stem of maximum height c. $30 \mathrm{~cm}$ lacking branching, but bearing abundant dichotomously branching laterals. He found no evidence for pronounced horizontal rhizomes, but showed branching leafless axes extending downwards, rather similar to the system in Huperzia selago. The stellate xylem with protoxylem embedded in the ends of the arms is also similar to that in the extant species (Kidston \& Lang 1920b), and contrasts with the terete strand surrounded by a broad uninterrupted zone of phloem in the presumed rhizomes. The leaves varied in size and shape, but differed from microphylls in that leaf traces, when present, did not enter the free parts of the leaves. On leaving the arm of the xylem, each trace girdled the cortex before entering the leaf base and ended in a club-shaped mass of rounded, darkly stained cells rather than aligned tracheids. Bhutta (1969) showed variation in leaf tip shape from rounded to more acuminate, and in section from circular to oval to more markedly dorsi-ventral. Some shoots had leaves with papillate epidermal cells, but these were absent on others. The very close insertion of persistent leaves on Asteroxylon stems hinders precise elucidation of phyllotaxis. Kidston \& Lang's (1921) illustration of free leaves close to an apex hints at a helical phyllotaxis (two sets of opposed parastichies), the arrangement most favoured by later authors (e.g. Chaloner \& MacDonald 1980; Kenrick \& Crane 1997). Bhutta (1969) described the leaves as in spiral or 'complex spiral' arrangements, but less crowded than in Kidston \& Lang's (1921) reconstruction and with space varying between specimens.

In the transition region between leafy shoot and rhizome, scale leaves, sometimes completely lacking vascularisation, were present. They contained fewer stomata (usually sunken) than in the more conventional microphylls and their pores were longer. Depressed guard cells were also present on stems and dorsi-ventral leaves, while more conventional examples characterised stems and the central parts of leaf bases where the leaves were long and fleshy, and oval in transverse section (Edwards et al. 1998). Stomata were always absent in distal parts of leaves. Anatomically the leafy shoots were notable in the presence of a pronounced trabeculate zone with abundant air spaces in the inner cortex. A single specimen contained a putative endodermis. This would be the only record of an endodermis in early land plants. The same leafy specimen shows an unusual form of endogenous branching, but the fate of the branch could not be determined.

The cauline lateral sporangia of Asteroxylon were interspersed between leaves close to the tip of the leafy shoot, but without any consistent relationships with the microphylls (Lyon 1964). The tangentially flattened sporangia, up to $7 \mathrm{~mm}$ in diameter, were bivalved with a slit extending around the distal margin. In face view, they were either reniform or had a central distal concavity (Bhutta 1969). The eusporangium was homosporous with spores about $50 \mu \mathrm{m}$ in diameter, although most sporangia are empty. They had long stalks with pronounced vascular supply. Each strand became spindle-shaped below the sporangium before fanning out into a kind of transfusion tissue at its base. The apex of stalk formed a small pad of tissue in the bottom of the sporangial cavity (Lyon 1964; Bhutta 1969). The most detailed and accurate reconstructions of fertile shoots are in Bhutta's (1969) thesis. He recorded one with 19 sporangia, some in small groups, some isolated, but with no indications of a strobilus.

1.4.2. Relationships. Kidston \& Lang (1920b), while recognising major similarities in the vegetative shoots of Asteroxylon and extant Lycopodium, were influenced in their deliberations on affinities, by information both from Dawson's Gaspé compression assemblages (Dawson 1871) and the associated 'psilophyte'-like fertile branches (see Nothia) in the Chert. Consequently, they placed Asteroxylon, together with Psilophyton princeps in a new family, Asteroxylaceae, alongside the Rhyniaceae in the Psilophytales. Scott (1923) concluded that, again based on the association of fertile and vegetative parts, in the absence of the former, Asteroxylon could have been either an early lycopod or a lycopod precursor, but that it resembled the Psilotales in lacking roots.

Confirmation of the fertile region in which lateral cauline sporangia are randomly distributed among leaves (Lyon 1964; Bhutta 1969) reinforced the lycophyte affinities, although for some authors, the incomplete leaf venation and lack of precise relationship between single adaxial sporangium and microphyll (sporophyll) led to the appelation 'prelycophyte' or 'prelycopods' (Niklas \& Banks 1990; Gensel 1992; Gensel \& Berry 2001). Indeed, Rayner (1984) had earlier erected a new class-Drepanophycopsida-for plants with the vegetative organisation of lycopods and zosterophyll reproduction. In contrast, Hueber (1992) appears to have accepted Asteroxylon as a lycopod.

In the cladistic analysis of Kenrick \& Crane (1997), Asteroxylon, Baragwanathia and Drepanophycus, grouped in the 


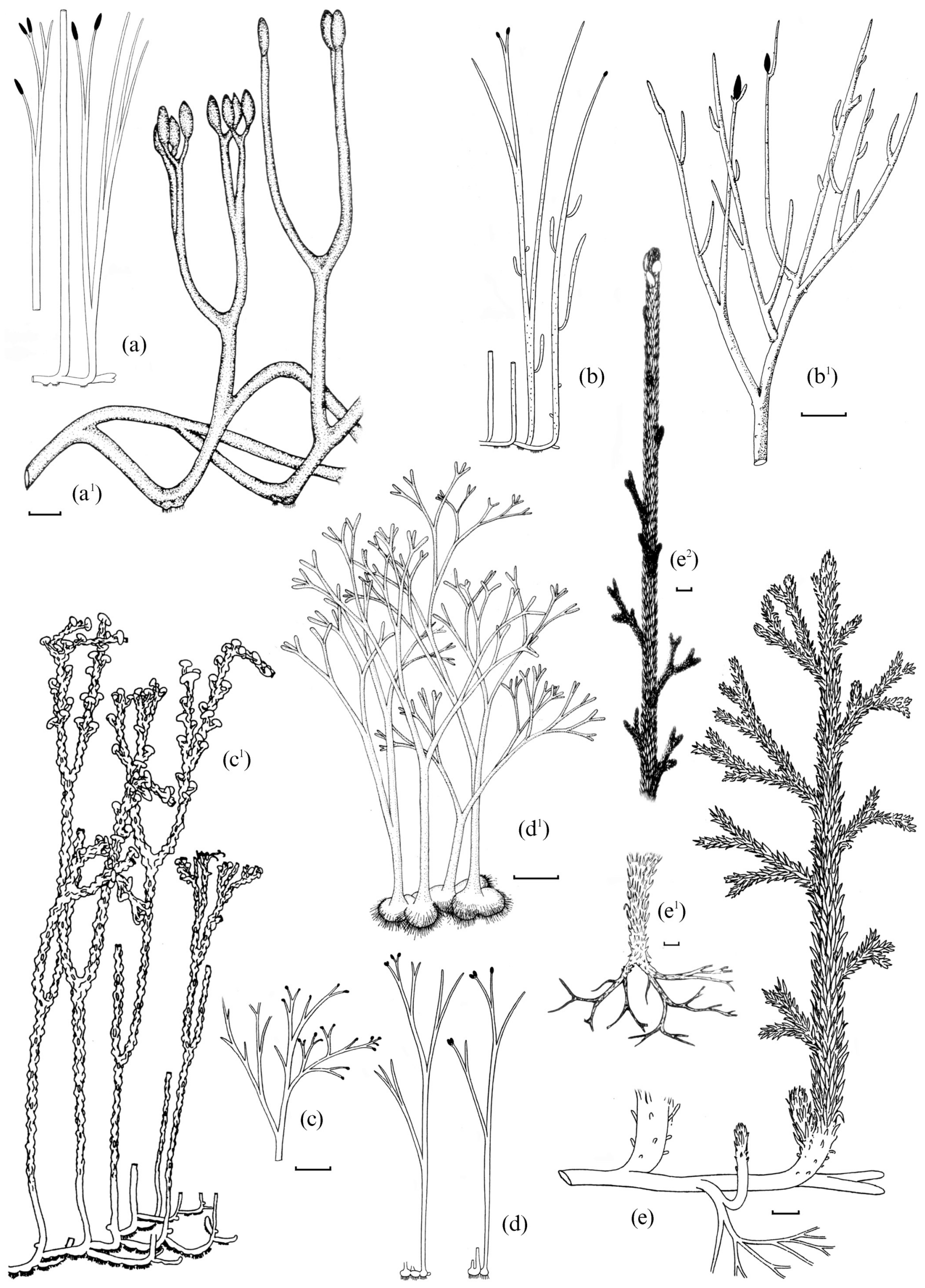


Drepanophycaceae, were recognised as the stem group in the Lycopsida, while in a cladogram of Gensel (1992), Asteroxylon was resolved as sister to all other lycopod (s.l.) taxa.

Such publications demonstrate that Asteroxylon provides an excellent example of how the fossil record, and in this case the fossil record at its best, can yield what has traditionally been called an intermediate taxon and can reinforce, in cladistic phylogenetic reconstructions, the value of the inclusion of extinct taxa in analyses.

\subsection{Nothia aphylla Lyon 1964 ex Høeg 1967 (Figs 1c, $\left.\mathrm{c}^{\prime}, 2 \mathrm{~h}, \mathrm{i}, \mathrm{p}, 3 \mathrm{l}\right)$}

1.5.1. Description. The recent reconstruction of Nothia (Kerp et al. 2001) was based on the combined studies of these authors (mainly basal vegetative regions) and of El-Saadawy \& Lacey (1979; aerial reproductive parts). It shows a plant c. $20 \mathrm{~cm}$ tall with dichotomous branching in upright axes, but very complex branching in basal regions commensurate with clonal and intermittent growth - each aerial part being called a plantlet (Kerp et al. 2001). The most striking morphological features of all except basal aerial axes and rhizomes are the numerous overlapping elliptical to lens-shaped emergences covering the surface - each terminating in a stoma (Fig. $2 \mathrm{~h}$ ). They were $<350 \mu \mathrm{m}$ high and $<1 \cdot 2 \mathrm{~mm}$ long. Anatomically distinguishing features are an epidermis composed of elongate giant cells $(<1.6 \mathrm{~mm}$ long) and alternating files of smaller cells, and an exarch xylem strand whose tracheids lack distinctive thickenings (Fig. 2i). Kerp et al. (2001) provided a detailed account of the vascularisation of the axes in the rhizomatous regions, and particularly, the linking of the vascular core with the elongate ridges (connective) bearing rhizoids on the lower surfaces. Reniform to oval bivalved lateral eusporangia (c. $3 \mathrm{~mm}$ wide and $1.5 \mathrm{~mm}$ high) were arranged in loose terminal strobili. Sporangial arrangement were very variable, and described as spiral to semiverticillate or, occasionally, as terminal clusters (El-Saadawy \& Lacey 1979). Their stalks were at least as long as sporangial height and strongly vascularised. Dehiscence was by means of an extensive slit, but not quite as long as the convex margin (details are given in Kerp et al. 2001). The plant was homosporous. Trilete spores (c. $65 \mu \mathrm{m}$ diameter) are often seen in tetrads and have a faint surface reticulum or are smooth.

1.5.2. Relationships. Since Kidston \& Lang (1920b) briefly described 'peculiar' fossils with leafless, slender, branched axes and terminal pear-shaped sporangia, showing distal dehiscence, as possible fertile regions of Asteroxylon, further abundant material investigated in detail by El-Saadawy (1966), El-Saadawy \& Lacey (1979) and Kerp et al. (2001) has made this independent sporophyte, now known as Nothia aphylla, among the most completely known plant in the Rhynie chert, but its affinities are by no means clear cut. In its bivalved lateral sporangia and exarch xylem, it appears to have affinities with the zosterophylls, as was originally concluded by ElSaadawy (1966) and reiterated following a cladistic analysis by Kenrick \& Crane (1997), in which lack of tracheidal thickenings was interpreted as an evolutionary loss. Hueber (1992) had not included it in his reinterpretation of the Zosterophyllophytina. Banks (1975) had included it as a questionable rhyniophyte, but Edwards \& Edwards (1986) omitted it from that subdivision. El-Saadawy \& Lacey (1979) had earlier listed characters found in both zosterophylls and rhyniophytes.

Detailed scrutiny of the character states provides some explanation for the indecision. Considering tracheidal ultrastructure, tracheids in Nothia have a uniformly thickened wall and, thus, appear to lack the G-type tracheids which typify the lycophyte/zosterophyll clade. The taxonomic significance of this difference is perhaps lessened by the comments on Aglaophyton and Rhynia water-conducting cells. Considering sporangial position and distribution, these are certainly not as regular and, hence, predictable as in most zosterophylls. The vascularised sporangial stalks variously inserted, but curving adaxially, are longer than those in the majority of zosterophylls and appear more stem-like particularly when, in a cluster of ultimate bifurcations, each branch terminates in a single sporangium. A further example of less determinate growth is seen in the sporangia which have united stalks, but a single cavity and two dehiscence slits. In the original diagnosis, sporangial arrangement was described as opposite to semiverticillate, but this oversimplifies the great variety and irregularity described by El-Saadawy \& Lacey (1979), which may or may not be associated with dichotomies of the main axial system. The sporangia themselves do indeed possess the zosterophyll character of two valves, showing splitting around the distal convex margin, but the mechanism of dehiscence at the cellular level was probably quite different. In the zosterophylls, where sporangia are anatomically preserved, a zone of thickwalled cells (marked in compression fossils by an increased thickness of coal) border the eventual dehiscence line (e.g. Ventarura here). However in Nothia, there is a decrease in wall thickness close to the dehiscence slit (El-Saadawy \& Lacey 1979), which is created in a band of very small cells (Kerp et al. 2001) perhaps by shrinkage of the cup-shaped thickenings in the latter (cf. a fern annulus) and schizogenous breakdown in a central line of slightly elongate cells. This superficial slit contrasts with the zosterophyll split that occurs at the base of a groove created by the thickened borders. Thus, mere scoring for presence or absence of sporangial characters in cladistic analyses can mask major developmental and histological differences, and in this case, sporangial characters may be homoplasous. Therefore, Nothia's taxonomic position remains unresolved.

\subsection{Trichopherophyton teuchansii Lyon \& Edwards (Figs 2q, r, 3d, e)}

1.6.1. Description. Described from very fragmentary remains (Lyon \& Edwards 1991), even the approximate height of this plant remains obscure, although stems reached $2.5 \mathrm{~mm}$ in diameter. They are unique among the Rhynie chert plants because they bore unicellular, rigid hairs (?spines) and terminated circinately. The stems branched isotomously and possibly pseudomonopodially, and contain terete exarch xylem strands with annular and spiral tracheids. Individual erect sporangia were unequally bivalved, with smaller and thinner adaxial valves apparently unarmed. Dehiscence was by means of a split at the base of a groove formed by the sporangial margins. Laevigate trilete spores were c. $55 \mu \mathrm{m}$ in diameter. Sporangial stalks were vascularised with a diffuse tracheidal sheath entering the base of the abaxial valve. The presence of

Figure 1 Reconstructions of Rhynie chert sporophytes. (a, a') Aglaophyton major: (a) After Kidston \& Lang 1921 ; (a') After D. S. Edwards 1986 (scale bar $=10 \mathrm{~mm}$ ). Reproduced by permission of the Linnean Society of London. (b, b') Rhynia gwynne-vaughanii: (b) After Kidston \& Lang 1921; (b') After D. S. Edwards 1980 (scale bar=5 mm). Reproduced with permission of Elsiever. (c, c') Nothia aphylla: (c) After Kidston \& Lang 1921; (c') After Kerp et al. 2001 (scale bar=10 mm). Reproduced with permission of Columbia University Press. (d, d') Horneophyton lignieri: (d) After Kidston \& Lang 1921; (d') After Eggert 1974 (scale bar=5 mm). Reproduced by permission of the Botanical Society of America. (e, e', e²) Asteroxylon mackiei: (e) After Kidston \& Lang 1921; (e', $\left.\mathrm{e}^{2}\right)$ Redrawn from Bhutta 1969 (scale bar $=1 \mathrm{~cm}$ ). 

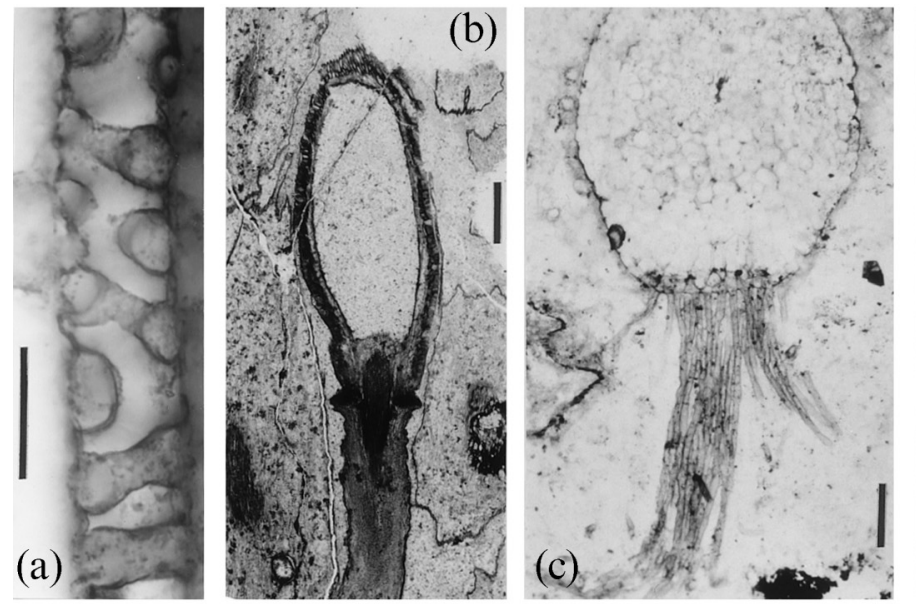

(d)
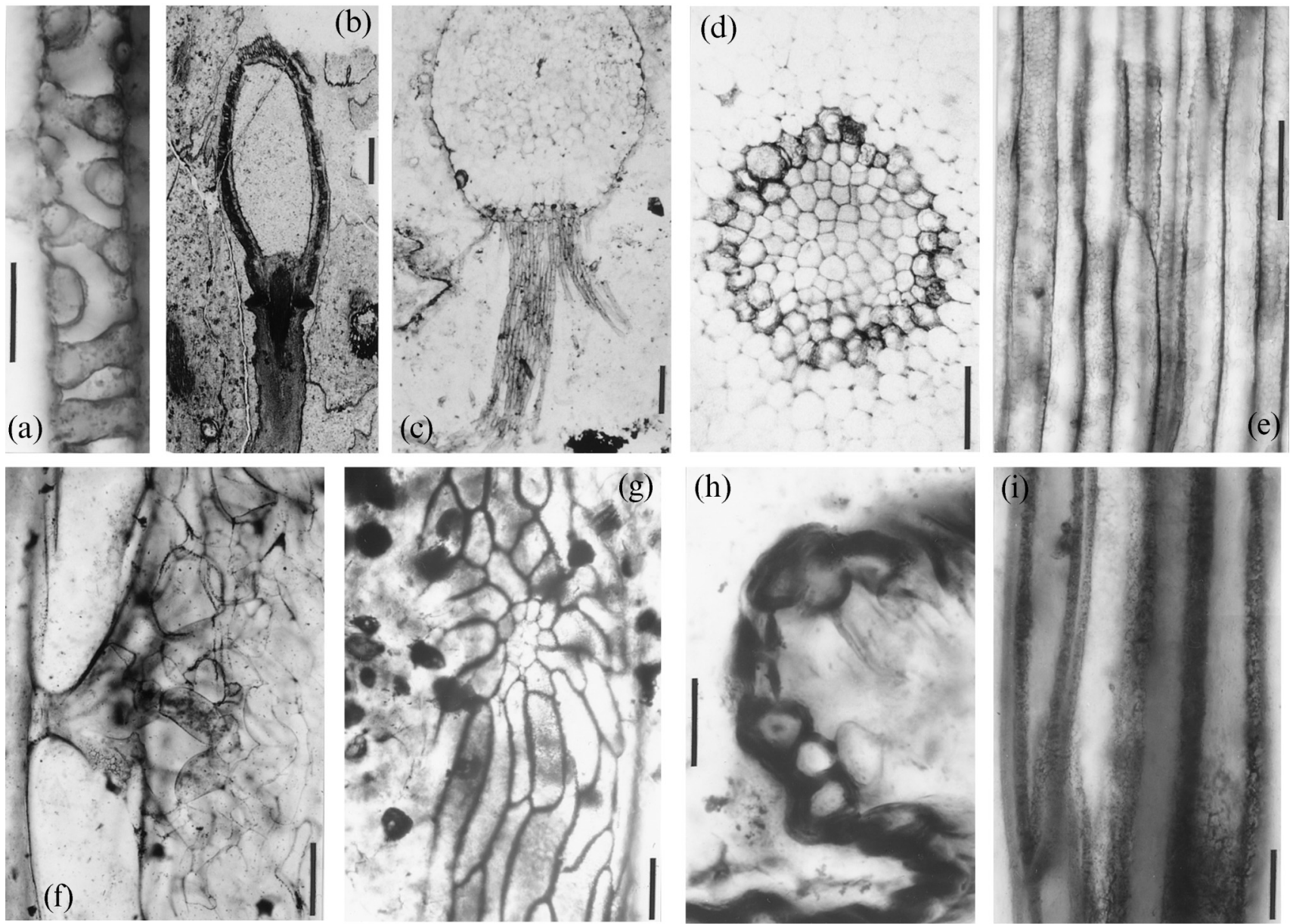

(j) 100 ( 6.) Fin
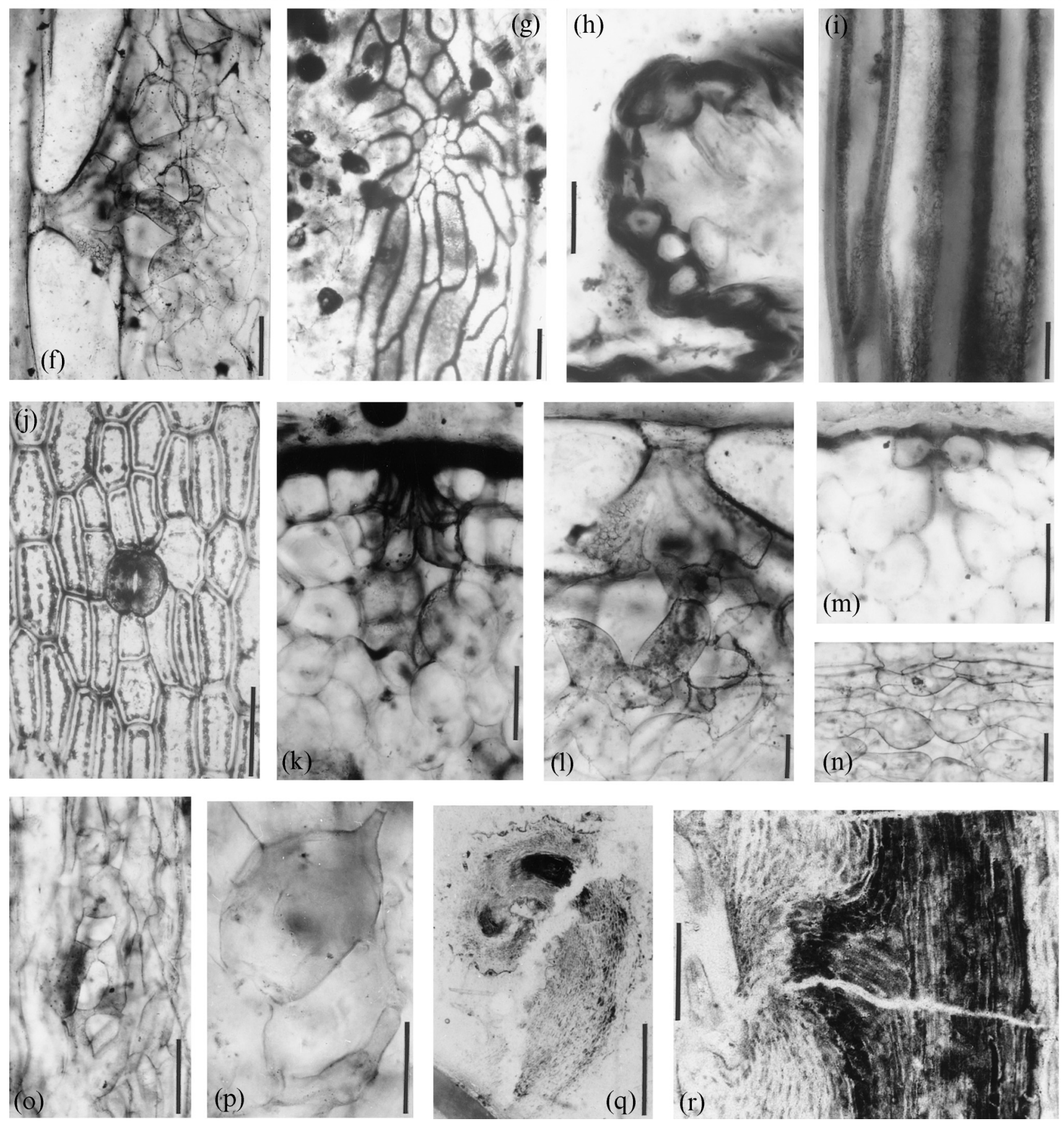
a strobilus cannot be verified; it seems more likely that there were zones of sporangia. Smooth rhizoidal axes with similar tracheidal anatomy, some penetrating (growing through) spinous examples, are possibly the rhizomes of Trichopherophyton (see section 2.3).

1.6.2. Relationships. The lateral bivalved sporangia and exarch xylem indicate affinities with the zosterophylls. Close scrutiny of longitudinal sections, particularly of the presumed rhizomes, reveals some indication of additional structures between the secondary thickenings which are suggestive of G-type tracheids. Evidence for fertile characteristics, both in sporangial anatomical detail and arrangement, is limited. However sporangial orientations with distally directed 'upright' sporangia with abaxial (slightly smaller) and adaxial valves resemble those in Zosterophyllum, but with little evidence in the Rhynie plant of a distinct stalk. In the longest well-preserved specimen, sporangia were arranged in close proximity in one row, although not directly 'superpositioned'. A sterile axis shows a circinate tip, a possible indicator of indeterminate growth following a period of reproduction. Only one Zosterophyllum species, $Z$. divaricatum, unequivocally possesses circinate tips, although this might relate to nonpreservation of immature axes in the remainder. Niklas \& Banks (1990) distinguished two major growth patterns within the zosterophylls: The first, characterised by Zosterophyllum, had distal spikes with a terminal sporangium and, hence, determinate growth, with pronounced vasculature in the sporangium stalk. The second was more diverse, with circinate tips and sporangial zones indicative of indeterminate growth, xylem elliptical in cross-section and a variety of surface outgrowths. Trichopherophyton possessed characters of both groups with its terete strand, strong vascularised stalks and, from circinate tips, presumed indeterminate growth.

\subsection{Ventarura lyonii Powell, Edwards \& Trewin (Fig. $3 \mathrm{f}, \mathrm{g}, \mathrm{k})$}

1.7.1. Description. This latest new genus comes from the Windyfield chert (Powell et al. 2000). It is based on dispersed fragments, the longest being c. $120 \mathrm{~mm}$ long. Aerial stems were smooth and dichotomously branched. The terete exarch xylem strand consisted of G-type tracheids. Circum-xylary tissues comprised thin-walled fusiform cells lacking intercellular spaces. The cortex is exceptional in that two zones of parenchymatous cells were separated by a conspicuous complete cylinder (between two and seven cells thick) of ambercoloured, thick-walled cells. These were elongate with truncated or tapering ends. The walls were three-layered and the lumina appear empty. Such features characterise sclerenchyma, a tissue not previously documented in the Rhynie chert, although cells in the peripheral regions of ?mature axes of Aglaophyton have thickened but not layered walls. The outer cortex in Ventarura is poorly preserved, and an epidermal layer has not been seen, although a cuticle with inward projections is present. The inner cortical cells have granular contents and abundant intercellular spaces. Eusporangia were borne laterally and were broadly attached to the stem, with a possibly fleshly abaxial valve and narrower adaxial one. In full valve view, they were circular to slightly pear-shaped. The plant was homosporous with mean spore diameter c. $67 \mu \mathrm{m}$. No trilete marks have been recorded. The exospore was probably bilayered, the reticulate or folded outer layer possessing a coarse granular outer surface. Dehiscence was via a slit situated at the base of a groove flanked by thickened valve borders which extended around much of the convex margin, but not to the bases of the valves. Sporangia were quite closely spaced, probably inserted in two rows and possibly forming a strobilus. Associated axes with similar tracheidal anatomy, but sometimes showing xylem medullation, bear unicellular ?rhizoids on all surfaces (Fig. 3f, g) and are possibly Ventarura's rhizomes. Branching was less regular and more frequent than in the aerial stems.

1.7.2. Relationships. The lateral bivalved sporangia, exarch xylem and G-type tracheids unequivocally relate this genus to the zosterophylls. However the distribution of sporangia and the symmetry of their arrangement remain equivocal. Limited information indicates that the sporangia were arranged in two rows, and their spacing suggests either a fertile zone or perhaps more likely a strobilus in which broadly attached sporangia, with abaxial and slightly smaller adaxial valves, were slightly inclined distally and show very little overlap. Thus, they generally resemble the genus Zosterophyllum in their orientation, but lack the well-defined stalks of the latter. Whether or not the fertile growth pattern was indeterminate or determinate sensu Niklas \& Banks (1990) cannot be resolved. This dilemma highlights both the advantages of (well-preserved) compression fossils for information on gross morphology and the frustrations caused by their lack of anatomical detail, which prevents detailed sporangial comparisons, in this case particularly with the compressed, coalified sporangia with apparently similar morphology, seen in Sawdonia ornata (Hueber 1992).

\section{The added value factors of the Rhynie chert}

In this section, some examples are presented of data revealed only by silicification of entire plant organs.

\subsection{Soft tissue preservation}

For the plant anatomist, the most important and unique contribution of the Rhynie chert to studies on early tracheophyte evolution must surely relate to parenchymatous tissues.

Figure 2 Anatomy in Rhynie Chert sporophytes, based on ground sections except 2b, c, q, r which are peels: (a) LS tracheid of Rhynia gwynne-vaughanii (scale bar $=10 \mu \mathrm{m})$; (b) LS sporangium and subtending axis in $R$. gwynne-vaughanii (scale bar=500 $\mu \mathrm{m}$ ); (c) TS rhizoid-bearing axis of $R$. gwynne-vaughanii (scale bar $=200 \mu \mathrm{m}$ ); (d) TS central region of Aglaophyton major (scale bar $=100 \mu \mathrm{m}$ ); (e) LS central region of $A$. major. Note faint reticulate patterning (scale bar $=100 \mu \mathrm{m}$ ); (f) LS outer region of aerial axis of Horneophyton lignieri with giant epidermal cells and sub-stomatal region (scale bar $=100 \mu \mathrm{m}) ;(\mathrm{g})$ LS emergence on H. lignieri sporangium showing a secretory organ (scale bar $=100 \mu \mathrm{m})$; $(\mathrm{h})$ LS emergence on Nothia aphylla with stoma at tip (scale bar $=50 \mu \mathrm{m}$;) (i) LS presumed water-conducting cells of $N$. aphylla (scale bar $=20 \mu \mathrm{m})$; (j) paradermal section of $A$. major (scale bar $=100 \mu \mathrm{m}) ;(\mathrm{k})$ TS stoma and substomatal region in A. major (scale bar $=100 \mu \mathrm{m}$ ); (1) LS stoma and substomatal cavity in $H$. lignieri (magnified from (f) (scale bar $=100 \mu \mathrm{m})$; (m) TS stoma and substomatal cavity in $R$. gwynne-vaughanii (scale bar=100 $\mu \mathrm{m}$ ); (n) LS spongy assimilatory tissue in outer cortex of $A$. major (scale bar $=100 \mu \mathrm{m})$; (o) LS similar region in $R$. gwynne-vaughanii (scale bar=100 $\mu \mathrm{m})$; (p) LS spongy assimilatory in N. aphylla emergence (scale bar $=50 \mu \mathrm{m}$ ); (q) LS hooked tip of Trichopherophyton teuchansii. Dark area is vascular strand (scale bar $=1 \mathrm{~mm}$; (r) Lateral meristems in T. teuchansii. Note vascular strand and hairs (scale bar=200 $\mu \mathrm{m}$ ).

(a), (e) \& (i): First published in Edwards 2003 and reproduced by permission of Blackwell Publishing Ltd.

(b), (q) \& (r): First published in Edwards 1994 and reproduced by permission of the Linnean Society of London.

(c) \& (j): First published in Edwards 1986 and reproduced by permission of Blackwell Publishing Ltd.

(d): First published in Edwards 1993 and reproduced courtesy of the New Phytologist Trust.

(f)-(h), (k)-(p): First published in Edwards et al. 1998 and reproduced by permission of Oxford University Press. 

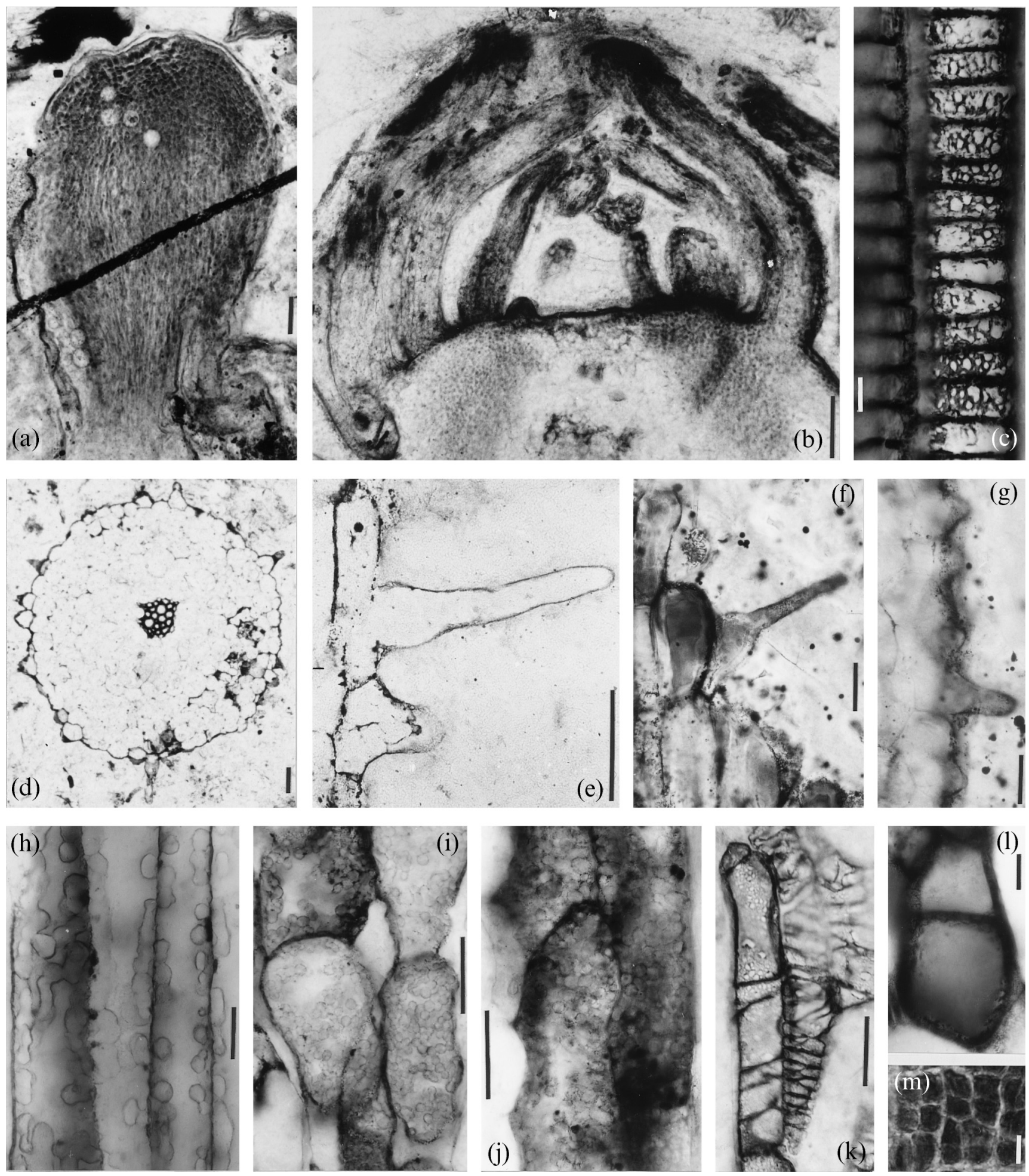

Figure 3 Anatomy of Rhynie and Windyfield cherts' sporophytes. All are ground sections except (d) and (e) which are peels. (a) LS apex of Rhynia gwynne-vaughanii (scale bar $=100 \mu \mathrm{m}$ ); (b) LS apex of Asteroxylon mackiei

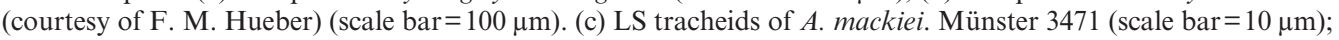
(d) TS axis associated with Trichopherophyton teuchansii (scale bar $=100 \mu \mathrm{m})$; (e) presumed rhizoids in axes associated with $T$. teuchansii (scale bar $=100 \mu \mathrm{m}$ ); (f, g) presumed rhizoids in axes associated with Ventarura lyonii (f) GLAHM 11402 (g) GLAHM 114037 (scale bars $=100 \mu \mathrm{m}$ ); (h) LS outer 'thickened' cells of central conducting strands of A. major showing coalescence of vesicles. Münster 346 (scale bar=20 $\mu \mathrm{m}$ ); (i) 'transition' cells in $A$. major rhizome. Münster 1876 (scale bar $=50 \mu \mathrm{m}$ ); (j) 'transition' tracheids in $R$. gwynne-vaughanii. Münster 2278 $($ scale bar $=50 \mu \mathrm{m}) ;(\mathrm{k})$ tracheidal cells in rhizomes associated with $V$. lyonii. GLAHM 114041 (scale bar $=50 \mu \mathrm{m})$;

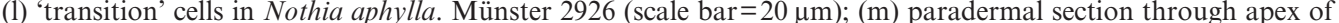
R. gwynne-vaughanii (scale bar $=10 \mu \mathrm{m})$.

(a) \& (b): First published in Edwards 1994 and reproduced by permission of the Linnean Society of London. (c), (h)-(l): First published in Edwards 2003 and reproduced by permission of Blackwell Publishing Ltd.

Dermal and vascular tissues (especially xylem) are also well represented in compressions and other forms of permineralisation. In the chert, the three-dimensional preservation of 'soft tissues' has been particularly informative as regards intercellular air space systems and presumed assimilatory tissues. Corner (1964) had regarded these aeration systems and 
internalised photosynthetic cells as mere details in the progression of plants from water to land, but the Rhynie chert plants demonstrate extensive sophistication early in the conquest. Guard cell anatomy (Fig. 2j) and stomatal frequencies have been acquired from variously preserved fossils (see Edwards et al. 1998), but only in the Rhynie chert silicifications have we information on substomatal cavities and presumed assimilatory tissues ('mesophyll'). Aglaophyton and Rhynia are broadly similar in that hypodermal cells produce a short canal/channel below the guard cells leading into a deep sub-stomatal cavity (Fig. 2k, m). Aglaophyton (Remy \& Hass 1996) differs from Rhynia in that the hypodermal cells are more elongate and thickened on walls adjacent to the canal, but in both, the latter has a cuticularised lining (Edwards et al. 1998). In Horneophyton, the exceedingly long epidermal cells cradle the guard cells, again forming a short canal above the substomatal cavity (Fig. $2 \mathrm{f}, 1)$. An extensive aerating system is seen in the parenchymatous cells lining the sides and base of these cavities. Cells, matching the diversity in spongy mesophyll of angiosperms (e.g. Meyer 1962), were sausage-shaped to globular and also characterised by a number of extensions ( $<6$ in Aglaophyton) presumably creating maximum surface area for $\mathrm{CO}_{2}$ absorption in an internalised humid atmosphere (Fig. 2h, o). Such concentrations of cells formed lens-shaped areas of assimilatory tissue below the stomata. The interstomatal areas (more extensive in these Rhynie plants because of low stomatal frequencies) show configurations of outer cortical cells which are reminiscent of certain types of palisade mesophyll. Thus, Remy \& Hass (1996) described files of cubic to cuboid cells separated by large intercellular spaces which are inserted at an angle to the surface in Aglaophyton. Similarly orientated cells occur in the depressed areas between the characteristic emergences of Nothia (Kerp et al. 2001) and in the outer cortex of Horneophyton (Edwards et al. 1998). Today, such arrangements are seen in photosynthesising tissues in linear leaves and stems of certain flowering plants (Meyer 1962). In Nothia, the outer cortical cells in the emergences themselves resemble those lining the substomatal cavities. They vary in size and length, and numbers of protrusions (Fig. 2p), with the largest intercellular spaces occurring towards the centre of the emergence. The guard cells occurring on the summits of the emergences (Fig. 2h) are somewhat atypical among Rhynie chert examples in that they usually open directly into the substomatal cavity. Nothia is also characterised by a unique epidermis in which between two and 12 files of \pm 'normal' short epidermal cells alternate with rows of giant cells $<1600 \mu \mathrm{m}$ long and up to $200 \mu \mathrm{m}$ deep. They are of similar width, but in surface view, they appear much narrower (10-20 $\mu \mathrm{m}$ wide) because the bulk of each cell is embedded in hypodermis (Kerp et al. 2001). Detailed observations such as these allow speculation on the functional anatomy of the structures (e.g. as water-storage structures).

Stomatal configurations and frequencies were used to infer high water use efficiency in several Rhynie plants in quantitative approaches to consideration of water relations (McElwain \& Chaloner 1995; Edwards et al. 1998). Similar conclusions were reached by Konrad et al. (2000) in calculations using the spatial data measurements on the tissues. While it has been inferred that low stomatal frequencies confirm modelled high concentrations of atmospheric $\mathrm{CO}_{2}$ (McElwain \& Chaloner 1995), anatomical characters which appear to minimise $\mathrm{H}_{2} \mathrm{O}$ loss were somewhat unexpected in plants growing in relatively wet habitats. For example, Aglaophyton was further hypothesised to possess adaptations (wall thickening and cutinisation) in basal regions of aerial axes to protect against flooding and defence against aquatic fungi (Remy \& Hass 1996). The absence of very extensive intercellular airspace systems remi- niscent of aquatic plants, where lack of oxygen in absorbing areas might interfere with water uptake, leaves the possibility that high silica concentration in ground water might have caused the latter. Physiological drought is experienced by a number of angiosperms colonising areas close to hot springs today. Adaptations to seasonal drought, as might be anticipated from the locality's palaeolatitude, seem unlikely in such a hot spring system.

Such deliberations show how detailed anatomical information of the type provided by the Rhynie chert sporophytes allow reasoned speculation of the plants' eco-physiology (e.g. Edwards et al. 1998; Konrad et al. 2000).

\subsection{Branching: from process to pattern (or lack of it!)}

Permineralisations involving large volumes of decaying or standing vegetation have the potential of providing very accurate three-dimensional reconstructions of extensive regions, both aerial and subaerial, of the higher plant sporophytes. The physical efforts involved in the production of accurate models as exemplified in the theses of Bhutta (1969) and D. S. Edwards (1973) are tedious and time-consuming, but to date, computer-based techniques such as those recently developed in the reconstruction of arthropods within nodules (Sutton et al. 2001), for example, have not been successfully employed (e.g. work in progress in Cardiff on Trichopherophyton spikes). Nevertheless, reconstructions produced by, for example, D. S. Edwards for R. gwynne-vaughanii (1980) and Aglaophyton (1986) and Kerp et al. (2001) for Nothia, show far greater complexity in branching than those produced by Kidston \& Lang (1921). The latter reflected the patterns now conventionally regarded as typical of the earliest land plant lineages, in which apical dichotomy produced isotomous or anisotomous branching, the latter usually accompanied by subsequent unequal growth resulting in varying extents of overtopping (e.g. Gosslingia breconensis), and eventually, a pseudomonopodial aerial system (e.g. Psilophyton spp.) or the $\mathrm{K}$ - or H-branching more characteristics of basal parts (e.g. Zosterophyllum spp.) (Edwards 1994). Further variation is exemplified by the development of lateral branching again showing regularity because it is associated with branch points. Examples include: axillary/subaxillary tubercles, as in Gosslingia (Edwards 1970) and parts of Anisophyton potonei (angularorgans: Remy et al. 1986); more extensive branching systems, downwardly directed in spiny Deheubarthia splendens (Edwards et al. 1989) and erect in Anisophyton gothani (Remy et al. 1986); smaller protuberances (?dormant structures) on the lower surfaces at the base of lateral branches in Sawdonia ornata (Rayner 1983); and aborted branches forming parts of trichotomies in Psilophyton dawsonii (Banks et al. 1975). A rare example of less ordered, clustered branches in a Lower Devonian tracheophyte was illustrated in the enigmatic tracheophyte, Bitelaria dubjanskii (Johnson \& Gensel 1992). In all these cases, anatomical information on the apices is lacking. Until recently, only the Rhynie chert plants provided this - the new examples being some naked tips in minute charcoalified axes, in which cells are visible but poorly preserved (Edwards et al. 2003).

Superb preservation is seen in the relatively few recorded tips of the main axes of $R$. gwynne-vaughanii (Fig. 3a, m). First illustrated by Kidston \& Lang (1917), they show in longitudinal section a cuticularised, dome-shaped tip with more or less equant cells comprising a bean-shaped area (c. $220 \mu \mathrm{m}$ deep) below the dermal layer, and in an adjacent tip, sectioned paradermally, packets of cells demonstrating the derivatives of multiple mitotic divisions. Intercellular spaces are lacking, as is any indication of an apical cell. The longitudinal, presumably median, section shows no distinct zonation, as might indicate a 
procambium in the $\sim 1 \mathrm{~mm}$ of axis preserved, although cells become less distinct and longer more proximally, whereas axis diameter decreases.

Less well preserved at the cellular level, but of similar overall construction, apices were described in Nothia (Kerp et al. 2001) and in Asteroxylon (Hueber 1992). The latter was based on a single \pm median longitudinal ground section through a lateral branch showing a flat apex with several leaf primordia at various stages of development (Fig. 3b). These include small mounds of poorly defined apical initials to adaxially curved linear primordia with evidence of vascular development ranging from procambial strands to welldeveloped leaf traces. In the same paper, Hueber (1992) illustrated a young leaf showing an apparently isolated undifferentiated procambial strand extending downwards towards the leaf trace and upwards into the microphyll. Whether or not this demonstrates centripetal and centrifugal development of the leaf trace remains equivocal since the route of the trace may have deviated from the plane of the section, notwithstanding it was ground rather than a peel.

Far more common in the chert sporophytes are lateral meristems, which although tending to be less well preserved at the cellular level, are more informative on branching processes. Trichopherophyton teuchansii is unique in that apical growth is achieved via uncoiling of the apex (Fig. 2q). In the rare example of a circinate tip, the apex itself is obscured by precociously developed unicellular spines, similar to those that cover the aerial axes (Lyon \& Edwards 1991). A group of meristematic cells occurs flush with the stem surface some distance below the apex, but facing the coiled tip (Fig. 2r). Its fate can only be conjectured. Although lateral sporangia might be anticipated to be initiated in this region, the presence of a substantial, but undifferentiated, vascular strand continuous with that of the main axis (and arising at right angles to it) is more suggestive of its being the beginnings of a stem. This interpretation may have implications for growth processes in zosterophylls with circinate vernation: in Trichopherophyton, overtopping was probably not preceded by the division of an apical meristem.

Lateral growth has also been inferred for $R$. gwynnevaughanii. D. S. Edwards (1980) suggested that apically produced sporangia may have been shed, with subsequent axial growth facilitated by the development of adventitious branches stimulated by the removal of the sporangium. D. S. Edwards (1980) also emphasised that adventitious branching, as originally discovered by Kidston \& Lang (1917), was far more common than dichotomous branching. Kidston \& Lang (1917) had described small examples as lateral buds associated with vegetative reproduction. Sometimes lacking vascular tissues when shed, their original positions were then marked by darkly staining wound reaction tissues terminating short 'stalks'. Similar regions were recorded, if rarely, on aerial axes of Aglaophyton by Remy \& Hass (1996), and were associated with saucer- or disc-like organs with numerous tuberculate outgrowths on the upper margins. These were interpreted as bulbil-like structures for vegetative propagation that had developed from arrested lateral meristems.

However, the latter are far more common on the basal regions and rhizomes of Aglaophyton and Nothia (Kerp et al. 2001), with significance for clonal and seasonal growth, regeneration and vegetative reproduction. The meristems themselves, represented by poliferations of cells occurring flush to the surface or as small mounds, were interpreted as nascent or dormant lateral apices. In Aglaophyton, Remy \& Hass (1996) described small, dome-shaped structures characterised by radiating files of cells as arrested apices. They occurred most frequently on basal (especially U-shaped) regions of the aerial axes and developed into second-order branches and bulbil-like organs. Those which developed two growing points (one with rhizoids) gave rise to the $\mathrm{H}$-shaped branching that typifies zosterophylls. In Nothia, Kerp et al. (2001) elucidated, with immense precision, a basal system of great complexity, in which they recognised at least three types of patches of meristematic cells on the dorsal surface of prostrate rhizomes. These were distinguished in terms of regularity of cell arrangement and size. Groups of large prismatic cells were compared with dormant or bud apices in Selaginella, while a second type comprising exclusively rectangular cells with no distinct initials were interpreted as potential primary axes. While demonstrating versatility in development in these early land plants, these studies reinforce the importance of growth from lateral meristems rather than by division of the apex in many of the Rhynie plants. Such a strategy has implications for vascular tissue development and there are numerous examples of a lack, at least initially, of continuity between daughter and subtending axes (e.g. in Aglaophyton; Remy \& Hass 1996), and even between rhizome and aerial stems (e.g. in Horneophyton; Kidston \& Lang 1920a) with presumed major consequences for water transport in these sporophytes.

\subsection{Water absorption}

The Rhynie chert plants provide the only evidence for the cellular nature of the tissues responsible for water absorption in early land plants. With the exception of Asteroxylon, rhizoids have been recorded in all the taxa known to Kidston and Lang, and on rhizomes associated with the two zosterophylls. In all cases, they are non-septate, and thus, more characteristic of tracheophytes than bryophytes. Their distribution varies with taxa. Only in the rhizomes associated with Ventarura and Trichopherophyton (Fig. 3d-g) are rhizoids developed on all sides/surfaces of the rhizome, suggesting that the organs were completely buried in the substrate. In these cases, the rhizoids themselves were quite short, $<450 \mu \mathrm{m}$ in 'Ventarura rhizomes' (Fig. 3f, g), where they were either isolated or in clumps, or $<250 \mu \mathrm{m}$ in Trichopherophyton-type rhizomes, where certain papillate epidermal cells may be developing examples (Fig. 3d, e). Longer examples have blunt tips. In Trichopherophyton, all are extensions to cells similar to the remaining epidermal cells, while the unicellular rigid spinous outgrowths on the aerial axes are borne on cells with oval outlines, rather than the usual longitudinally elongate types. Ventarura rhizoids have expanded bases, which reflect the markedly convex surfaces of the remaining epidermal cells, from whose apices the extensions developed. In Aglaophyton, patches of rhizoids $<1000 \mu \mathrm{m}$ long occur on lower surfaces of rhizomes, as reported by D. S. Edwards (1986) and Remy \& Hass (1996), and appear to be concentrated on the bulges on the bases of the U-shaped axes where they were in contact with the substrate. The upper surfaces of these axes have stomata. Remy \& Hass (1996) further reported the development of the rhizoidal areas from arrested apices marked by radiating wart-like configurations of cells. What little is known about the presumed rhizomatous region of $R$. gwynne-vaughanii is based on Kidston \& Lang (1917) (a dichotomously branching structure) and Bhutta's (1969) thesis. The latter showed that rhizoids were not confined to the hemispherical projections which characterise this taxon (see Fig. 2c), although the majority of the latter bore tufts of rhizoids towards the bases of the aerial axes.

In Nothia, rhizoids were borne on the lower surface of an axial rhizome and concentrated on the crest of an elongate ridge. They are c. $30 \mu \mathrm{m}$ wide and up to $1500 \mu \mathrm{m}$ long. Shorter, smaller examples have tapering tips, but in older ones, the latter are enlarged $(<50 \mu \mathrm{m}$ wide and $70 \mu \mathrm{m}$ long) 'with 
cap-like wall thickenings' (Kerp et al. 2001). The basal regions of Horneophyton comprised a cluster of tuberous structures. Illustrations of some sections show the entire lower surface covered with very long rhizoids, but others are devoid of them and, thus, suggest probable development in bands. This is in contrast to their ubiquitous occurrence over the lower surfaces of the rhizomes in Eggert's (1974) reconstruction.

In contrast to the above, rhizoids are not recorded on the smooth, dichotomously branching, presumed subterranean axes interpreted as comparable to a rooting system on Asteroxylon (Kidston \& Lang 1920b). Kidston \& Lang (1920b) illustrated a series of examples and intergradations occurring between typical leafy stems, axes with small thorn-like projections and smooth forms interpreted as rhizomes. Such morphological changes are accompanied by a change from stellate to terete xylem strands (Schweitzer 1983); however, there is no evidence of unequivocal root characters in the naked axes. Thus, an endodermis-like layer was illustrated only once by Kidston \& Lang (1920b), and this in a leafy shoot, and putative endogenous branching was recorded in the same specimen, but with no evidence for the fate of the lateral branch. Of all the Rhynie plants, Asteroxylon has the most highly developed intercellular space system that, combined with the lack of rhizoids, might indicate colonisation of a water-logged substrate.

\subsection{Xylem}

When Rhynie chert plants are demineralised by dissolution of the matrix, the coalified remains of xylem, presumably representing lignified material, show remarkably little integrity. This contrasts with fossil plant material released by demineralising carbonate (e.g. in Psilophyton) and iron sulphide (e.g. Gosslingia as in Kenrick \& Edwards 1988) perimineralisations. Thus, it is very difficult to elucidate ultrastructure using scanning electron microscopy, and when successful, small changes in topography might well relate to imprints of silica crystals (e.g. Kenrick \& Crane 1991). Therefore, at the ultrastructural level, tracheidal detail can be much more difficult to interpret.

Considering the zosterophyll/lycophyte clade, its representatives, i.e. Asteroxylon, Ventarura and Trichopherophyton, would be predicted to possess G-type tracheids. Kidston \& Lang (1920b) originally recorded the tracheids of Asteroxylon as possessing a peculiar type of spiral or annular thickening. However, Lemoigne \& Zdebska (1980) described irregular thickenings between secondary thickenings which they compared with Williamson's striations (seen in Carboniferous lepidodendrids), but concluded that they were the products of degradation. Thorough examination by Kenrick \& Crane (1991) revealed helical and annular tracheids with limited interconnections, in which the thickenings were two-layered with the darker one lining the lumen and more translucent core. This parallels the construction noted in Gosslingia tracheids more conventionally preserved (Kenrick \& Edwards 1988). Scanning electron microscopy of etched tracheids appeared to show simple perforations, $<5 \mu \mathrm{m}$ in diameter, in the region between thickenings. Similar micrographs were shown for fractured Ventarura tracheids (Powell et al. 2000), and lighter regions noted between the thickenings in light microscopy of longitudinal sections were taken as evidence for G-type tracheids. No equivalent tracheidal structures were detected in Trichopherophyton, but this might relate to the thinness of peel preparations.

Peels of the xylem of Asteroxylon (Fig. 3c) were used to demonstrate the chemical zonation in $2^{\circ}$ thickenings by Boyce et al. (2002) and related to the original wall macromolecules. The differential distribution of hydroxylated aromatic and alcohol (acid/or ether carbon) in the inner and outer regions of the tracheid wall were interpreted as reflecting the deposition of lignin and structural polysaccharides, although these biopolymers had been diagenetically altered. Analysis using very high resolution soft X-ray spectromicroscopy [carbon (ls) X-ray absorption near-edge spectroscopy (C-XANES)] showed a distinct outer layer characterised by strong X-ray absorption and a weaker inner domain. The former results from proportionally more aromatic $\mathrm{C}$ than in the inner area (where there is a greater abundance of $\mathrm{COOH}$ and $\mathrm{C}_{\mathrm{m}}-\mathrm{O}$ ) and is interpreted as demonstrating a higher proportion of lignin derivatives than those from cellulose and other polysaccharides.

Longitudinal sections of Rhynia gwynne-vaughanii show broad annular (D. S. Edwards 1980) and helical secondary thickenings (Fig. 2a), often with a mottled appearance. Detailed examination in light microscopy by Kenrick \& Crane (1991) revealed helical thickenings, each with a broad base and comprising, for the most part, spongy lacunae, some quite large $<4.5 \mu \mathrm{m}-$ but also very small ones. The lacunate zone was separated from the lumen by an opaque layer, ?100$300 \mu \mathrm{m}$ thick. Such ultrastructure is broadly comparable with that described for S-type tracheids, but the above authors were unable unequivocally to resolve any pits or micropores. It is perhaps worth noting here that Kidston \& Lang (1917) found no evidence for tracheidal thickenings in older axes.

There have been no detailed investigations of Horneophyton vascular tissues, which occurred in the upright axes, but surprisingly, were lacking in their tuberous bases. The centrarch terete xylem strand, whose central area is frequently disorganised, comprised tracheids with helical or irregular connected thickenings (Kidston \& Lang 1920a), although these may not be apparent in decayed examples. They were shorter and wider towards the base, and gradually merged into the brown-coloured tissues which characterise the central area of the rhizomes.

Possibly the most extensively scrutinised and still least understood conducting cells in the Rhynie chert plants are those in Aglaophyton, whose apparent lack of conventional tracheidal thickenings persuaded D. S. Edwards (1986) to erect a new genus for the former Rhynia major and to emphasise similarities with moss hydroids. In those stelar representatives considered typical, the presumed phloem surrounded a terete strand of elongate cells with uniformly thickened walls, the central area having thinner walls than the peripheral cylinder (Fig. 2d). However, D. S. Edwards (1986) and, earlier, Lemoigne \& Zdebska (1980) had described a very regular reticulate wall patterning (Fig. 2e) that they concluded was an abiotic taphonomic artefact, associated either with degradation or silica crystallisation, a similar pattern having been reported in other tissues. Even earlier, in the original description of Rhynia major, Kidston \& Lang (1920a, p. 609) had noted a 'porous thickening' extending throughout the lumina of these cells, but they concluded that 'from the examination of many specimens we are convinced that this appearance is due to an alteration of the original thickening, and that it would not be wise at present to attach any weight to it'. Globular structures filling the lumina were subsequently illustrated in the 'transition' cells linking the central strand of a rhizome with rhizome-bearing regions of Aglaophyton (Fig. 3i) and in its gametophyte by Remy \& Hass (1996), and in the outer cells of the water-conducting strand in the aerial axes of the gametophyte by D. Edwards (2003), who mentioned the hypothesis of Kerp and Hass (pers. comm. 2003) that a lining layer was produced by fusion of these vesicles (Fig. 3h). A bilayered wall based on partial detachment of the inner had earlier been suggested by D. S. Edwards (1986). 
In contrast there is general consensus that the elongate strongly tapering central cells (Fig. 2i) in Nothia aphylla were uniformly $(2-3 \mu \mathrm{m})$ thick-walled. Exceptional examples show separation of an inner wall except at the corners: dark staining is interpreted as indicating the presence of phenolic substances (?lignin).

\subsection{Short distance transport}

The preceding account has concentrated on water-conducting tissues extending longitudinally in axial systems and concluded to have been involved in long distance transport. The Rhynie chert sporophytes show that tissues, broadly equivalent to transfusion tissues, had already evolved by Lower Devonian times and have been termed transfusion (Remy \& Hass 1996: Aglaophyton), transition (Kerp et al. 2001: Nothia) or linking (Bhutta 1969: R. gwynne-vaughanii) cells. The most convincing examples are short cells, two to three times as long as wide, with irregular outlines, which often mould the convex curvature of surrounding thin-walled cells. In all, the wall thickening is identical to that in the sporophyte xylem. Variation occurs in groupings and location. Thus, in rhizomes associated with Ventarura, short lineages of cells show lighter reticulate areas characteristic of G-type tracheids (Fig. 3k). They occur in rhizomes showing closely spaced bifurcations, the anomalous branching probably reflecting a tufted growth form. A far closer relationship to water absorption itself is seen in Nothia and Aglaophyton. In the latter, strands (less than six) of cells filled with vesicles (Fig. 3i) or lining the lumen (transfusion or transition cells) connect the rhizome xylem with the hypodermis of rhizoidal bulges. The number of strands is the same as the number of surface initials over the surface of the bulge (Remy \& Hass 1996). Similarly shaped cells filled with vesicles form 'transition' tracheids, emanating from the main xylem strands of aerial axes of $R$. gwynne-vaughanii (see Edwards 2003. Fig. 3j), marking the positions of adventitious branches although are not continuous with their vascular system.

In Nothia (Kerp et al. 2001), uniformly thickened walls (Fig. 31) of similar thickness $(2-3 \mu \mathrm{m})$ to the fusiform cells in the main axes are arranged in longitudinal files forming a bridge of tissue (the connective) between the hypodermis of the rhizoidal ridge and the stele. The thick-walled cells are intermingled with thin-walled examples lacking intercellular spaces. The latter are intermediate in size and shape between the longitudinally elongate 'phloem' cells of the stele and cuboidal hypodermal cells, and have been assumed to have had a water and nutrient-conducting function. The darkly stained, poorly preserved cells at the centre of the bulbous rhizomes of Horneophyton may also act in short distance transport, connecting with the more conventional tracheids of the upright axes.

The more detailed accounts of these tissues (e.g. Kerp et al. 2001) clearly demonstrate that they are consequent to the development of lateral structures and are not apical meristem derivatives. In the case of Nothia, for example, the short, water-conducting cells traversing the 'phloem region' must have been produced by de-differentiation of phloem cells, either food-conducting or parenchyma. Dedifferentiation, often accompanied by cell division, is also seen in wound responses. Thus, in Aglaophyton (Remy \& Hass 1996), where vascular tissues may have been destroyed, probably by fungal or bacterial infection, new anomalous vascular tissues may develop in the phloem or in the inner cortex, while in $R$. gwynne-vaughanii, new vascular tissues are differentiated within the infected region.

\section{And the down side?}

Persistent searching through systematic sectioning and screening has filled in many of the questions unanswered by Kidston and Lang's pioneering work. Particularly impressive in terms of completeness is our information on the 'slender, branched, leafless axes with peculiar structure and pear-shaped sporangia' thought by the above authors to be probably the fertile region of Asteroxylon, but now known as Nothia aphylla (an even more equivocal affinity!). Revisiting of $R$. gwynnevaughanii and Rhynia (Aglaophyton) major has added information on anatomy and gross morphology, leading to a questioning of the distinction of the two genera.

Detailed ultrastructure of presumed phloem still remains obscure, perhaps understandably so as sieve pores fall into the size range of silica crystals (Satterthwait \& Schopf 1972). However, as our understanding of silicification improves (Channing 2001; Channing \& Edwards 2004), it becomes opportune to reexamine in detail the cells surrounding the xylem in all the chert plants.

Fortuitous sections will surely eventually lead to whole plant reconstructions of Ventarura and Trichopherophyton, and a better understanding of the rooting systems of Asteroxylon. Such studies combine serendipity with hard work!

The present author started by commenting on the comparatively few taxa in the chert. The missing plants (at least compared with coeval assemblages preserved in clastic rocks of the Old Red Continent) are characterised by an abundance of thick-walled tissues (D. Edwards \& Richardson 2004). Ventarura has a cortical zone of cells with beautifully preserved three-layered walls-even here different because it is deep seated compared with peripheral stereomes of other coeval zosterophylls. The absent taxa also encompass the very small plants now known to have formed a turf-like vegetation at least until the end of the Lochkovian (D. Edwards 1996), and to include the permanent tetrad and dyad producers. In Ordovician and Silurian times, these spores were thought to have been produced by bryophytes, and whilst their parents may have become extinct before the Rhynie hot springs were active, it is surprising that there are no records to date of bryophytes in the cherts.

Such gaps in our knowledge provide the stimulus for further research. As is obvious from this symposium, the Rhynie cherts continues to astound. The present author concludes by reiterating the words of Kidston \& Lang (1920a) who, in naming the specific epithet of Horneophyton in honour of Professor Lignier, revealed that they had been of the opinion that, in his theories relating to the appearance of the earliest vascular plants, he had indulged in 'acute morphological speculations' (Lignier 1908), 'some of which gain confirmation and reality from the discovery of these simple types of Vascular Cryptogams'. Long may this continue.

\section{Acknowledgements}

I remain exceedingly grateful to Hans Kerp and Hagen Hass for the generous and unselfish use of the information they have gathered, and for supplying me with illustrations. I thank Lindsey Axe for her expert technical support.

\section{References}

Banks, H. P. 1968. The early history of land plants. In Drake, E.T. (ed.) Evolution and Environment: A Symposium Presented on the Occasion of the One Hundredth Anniversary of the Foundation of the Peabody Museum of Natural History at Yale University, 73-107. New Haven, Connecticut: Yale University Press. 
Banks, H. P. 1975. Reclassification of Psilophyta. Taxon 24, 401-13.

Banks, H. P. 1992. The classification of early land plants - revisited. The Palaeobotanist 41, 36-50.

Banks, H. P., Leclercq, S. \& Hueber, F. M. 1975. Anatomy and morphology of Psilophyton dawsonii, sp.n. from the late Lower Devonian of Quebec (Gaspé), and Ontario, Canada. Palaeontographica Americana 8, 77-127.

Bhutta, A. A. 1969. Studies on the flora of the Rhynie Chert. Unpublished Ph.D. thesis, University of Wales, Cardiff.

Bhutta, A. A. 1973a. On the spores (including germinating spores) of Rhynia major Kidston and Lang. Biologia 19, 47-57.

Bhutta, A. A. 1973b. On the spores (including germinating spores) of Horneophyton (Hornea) lignieri (Kidston and Lang) Barghoorn and Darrah (1938). Pakistan Journal of Botany 5, 45-55.

Boyce, C. K., Cody, G. D., Feser, M. Jacobsen, C., Knoll, A. H. \& Wirick, S. 2002. Organic chemical differentiation within fossil plant cell walls detected with x-ray spectromicroscopy. Geology 30, 1039-42.

Chaloner, W. G. \& MacDonald, P. 1980. Plants Invade the Land. Glasgow: HMSO for the Royal Scottish Museum, Edinburgh.

Channing, A. 2001. Processes and environments of vascular plant silicification. Unpublished $\mathrm{PhD}$ thesis, Cardiff University.

Channing, A. \& Edwards, D. 2004. Experimental taphonomy: silification of plants in Yellowstone hot-spring environments. Transactions of the Royal Society of Edinburgh: Earth Sciences 94 (for 1993), 503-21.

Corner, E. J. H. 1964. The Life of Plants. London: Weidenfeld and Nicolson.

Dawson, J. W. 1871. Report on the fossil land plants of the Devonian and Upper Silurian formations of Canada. Geological Survey of Canada Publication 428, 1-92.

Edwards, D. 1970. Further observations on the Lower Devonian plant, Gosslingia breconensis Heard. Philosophical Transactions of the Royal Society of London B 258, 225-43.

Edwards, D. 1986. Preservation in early vascular plants. Geology Today 2, 176-81.

Edwards, D. 1993. Tansley Review No. 53. Cells and tissues in the vegetative sporophytes of early land plants. New Phytologist 125, 225-47.

Edwards, D. 1994. Towards an understanding of pattern and process in the growth of early vascular plants. In Ingram, D. S. \& Hudson, A. (eds) Shape and Form in Plants and Fungi. Linnean Society Symposium Series No. 16, 39-59. London: Academic Press.

Edwards, D. 1996. New insights into early land ecosystems: a glimpse of a Lilliputian world. Review of Palaeobotany and Palynology $\mathbf{9 0}$, 159-74.

Edwards, D. 2003. Xylem in early tracheophytes. Plant, Cell and Environment 26, 57-72.

Edwards, D., Kerp, H. \& Hass, H. 1998. Stomata in early land plants: an anatomical and ecophysiological approach. Journal of Experimental Botany 49 (Special Issue), 255-78.

Edwards, D., Kenrick, P. \& Carluccio, L. M. 1989. A reconsideration of cf. Psilophyton princeps (Croft and Lang, 1942), a zosterophyll widespread in the Lower Old Red Sandstone of South Wales. Botanical Journal of the Linnean Society 100, 293-318.

Edwards, D., Axe L. \& Duckett, J. G. 2003. Diversity in conducting cells in early land plants and comparisons with extant bryophytes. Botanical Journal of the Linnean Society 141, 297-347.

Edwards, D. \& Edwards, D. S. 1986. A reconsideration of the Rhyniophytina, Banks. In Spicer, R. A. \& Thomas, B. A. (eds). Systematic and Taxonomic Approaches in Palaeobotany. The Systematics Association Special Volume No. 31, 199-220. Oxford: Clarendon Press.

Edwards, D. \& Richardson, J. B. 2000. Progress in reconstructing vegetation on the Old Red Sandstone Continent: two Emphanisporites producers from the Lochkovian sequence of the Welsh Borderland. In Friend, P. F. \& Williams, B. P. J. (eds) New Perspectives on the Old Red Sandstone. Geological Society, London, Special Publication 180, 355-70.

Edwards, D. \& Richardson, J. 2004. Silurian and Lower Devonian plant assemblages from the Anglo-Welsh Basin a palaeobotanical and palynological synthesis. In Williams, B. P. J., Marriott, S. B. \& Hillier, R. D. (eds) The Lower Old Red Sandstone of the Welsh Basin. Geological Journal Special Issue.

Edwards, D. S. 1973. Studies on the flora of the Rhynie Chert. Unpublished Ph.D. thesis, University of Wales, Cardiff.

Edwards, D. S. 1980. Evidence for the sporophytic status of the Lower Devonian plant Rhynia gwynne-vaughanii Kidston and Lang. Review of Palaeobotany and Palynology 29, 177-88.
Edwards, D. S. 1986. Aglaophyton major, a non-vascular land plant from the Devonian Rhynie Chert. Botanical Journal of the Linnean Society 93, 173-204.

Eggert, D. A. 1974. The sporangium of Horneophyton lignieri (Rhyniophytina). American Journal of Botany 61, 405-13.

El-Saadawy, W. El-S. 1966. Studies on the flora of the Rhynie Chert. Unpublished Ph.D. thesis, University of Wales, Cardiff.

El-Saadawy, W. El-S. \& Lacey, W. S. 1979. Observations on Nothia aphylla Lyon ex Høeg. Review of Palaeobotany and Palynology 27, $119-47$.

Frey, W., Hilger, H. H. \& Hofmann, M. 1996. Water-conducting cells of extant Symphyogyna-type metzgerialean taxa: ultrastructure and phylogenetic implications. Nova Hedwigia 63, 471-81.

Gensel, P. G. 1992. Phylogenetic relationships of the zosterophylls and lycopsids: evidence from morphology, paleoecology and cladistic methods of inference. Annals of the Missouri Botanical Garden 79, 450-73.

Gensel, P. G. \& Berry, C. 2001. Early lycophyte evolution. American Fern Journal 91, 74-98.

Halle, T. G. 1916. A fossil sporogonium from the Lower Devonian of Röragen in Norway. Botaniska Notiser, 79-81.

Halle, T. G. 1936. Notes on the Devonian genus Sporogonites. Svensk Botanisk Tidskrift 30, 613-23.

Hass, H. 1991. Die Epidermis von Horneophyton lignieri (Kidston \& Lang) Barghoorn \& Darrah. Neues Jahrbuch für Geologie und Paläontologie Abhandlungen 183, 61-85.

Hass, H. \& Remy, W. 1991. Huvenia kleui nov. gen., nov. spec. - eine Rhyniophyte aus dem höhoren Siegen des Rheinischen Schiefergebirges. Argumenta Palaeobotanica 8, 131-68.

Hébant, C. 1973. Diversity of structure of the water-conducting elements in liverworts and mosses. Journal of the Hattori Botanical Laboratory 37, 229-34.

Hueber, F. M. 1992. Thoughts on the early lycopsids and zosterophylls. Annals of the Missouri Botanical Garden 79, 474-99.

Johnson, N. G. \& Gensel, P. G. 1992. A reinterpretation of the Early Devonian land plant, Bitelaria Istchenko and Istchenko, 1979, based on new material from New Brunswick, Canada. Review of Palaeobotany and Palynology 74, 109-38.

Kenrick, P., Remy, W. \& Crane, P. R. 1991. The structure of the water-conducting cells in the enigmatic early land plants Stockmansella langii Fairon-Demaret, Huvenia kleui Hass et Remy and Sciadophyton sp. Remy et al. 1980. Argumenta Palaeobotanica 8 , 179-91.

Kenrick, P. \& Crane, P. R. 1991. Water-conducting cells in early land plants: implications for the early evolution of tracheophytes. Botanical Gazette 152, 335-56.

Kenrick, P. \& Crane, P. R. 1997. The Origin and Early Diversification of Land Plants. Washington, DC: Smithsonian Institution Press.

Kenrick, P. \& Edwards, D. 1988. The anatomy of Lower Devonian Gosslingia breconensis Heard based on pyritized axes, with some comments on the permineralization process. Botanical Journal of the Linnean Society 97, 95-123.

Kerp, H., Hass, H. \& Mosbrugger, V. 2001. New data on Nothia aphylla Lyon 1964 ex El-Saadawy et Lacey 1979, a poorly known plant from the Lower Devonian Rhynie Chert. In Gensel, P. G. \& Edwards, D. (eds) Plants Invade the Land: Evolutionary and Environmental Perspectives, 52-82. New York, NY: Columbia University Press.

Kerp, H., Trewin, N. H. \& Hass, H. 2004. New gametophytes from the Early Devonian Rhynie chert. Transactions of the Royal Society of Edinburgh: Earth Sciences 94 (for 2003), 411-28.

Kidston, R. \& Lang, W. H. 1917. On Old Red Sandstone plants showing structure, from the Rhynie Chert Bed, Aberdeenshire. Part I. Rhynia gwynne-vaughani, Kidston and Lang. Transactions of the Royal Society of Edinburgh 51, 761-84.

Kidston, R. \& Lang, W. H. 1920a. On Old Red Sandstone plants showing structure, from the Rhynie Chert Bed, Aberdeenshire. Part II. Additional notes on Rhynia gwynne-vaughani, Kidston and Lang; with descriptions of Rhynia major, n.sp. and Hornea lignieri, n.g., n.sp. Transactions of the Royal Society of Edinburgh 52, 603-27.

Kidston, R. \& Lang, W. H. 1920b. On Old Red Sandstone plants showing structure, from the Rhynie Chert Bed, Aberdeenshire. Part III. Asteroxylon mackiei, Kidston and Lang. Transactions of the Royal Society of Edinburgh 52, 643-80.

Kidston, R. \& Lang, W. H. 1921. On Old Red Sandstone plants showing structure, from the Rhynie Chert Bed, Aberdeenshire. Part IV. Restorations of the vascular cryptogams, and discussion of their bearing on the general morphology of the Pteridophyta and the origin of the organisation of land plants. Transactions of the Royal Society of Edinburgh 52, 831-54. 
Konrad, W., Roth-Nebelsick, A., Kerp, H. \& Hass, H. 2000. Transpiration and assimilation of Early Devonian land plants with axially symmetric telomes-simulations on the tissue level. Journal of Theoretical Biology 206, 91-107.

Lemoigne, Y. \& Zdebska, D. 1980. Structures problematiques observées dans des axes provenant du Chert Dévonien de Rhynie. Acta Palaeobotanica 21, 3-8.

Lignier, O. 1908. Sur l'évolution morphologique du règne végétal. Assocation Français Avancement des Sciences 1908, 530-42.

Lyon, A. G. 1964. Probable fertile region of Asteroxylon mackiei K. and L. Nature 203, 1082-3.

Lyon, A. G. \& Edwards, D. 1991. The first zosterophyll from the Lower Devonian Rhynie Chert, Aberdeenshire. Transactions of the Royal Society of Edinburgh: Earth Sciences 82, 323-32.

McElwain, J. C. \& Chaloner, W. G. 1995. Stomatal density and index of fossil plants track atmospheric carbon dioxide in the Palaeozoic. Annals of Botany 76, 389-95.

Meyer, F. J. 1962. Das trophische Parenchym A. Assimilations gewebe. In Zimmermann, W. \& Ozenda, P. G. (eds) Handbuch der Pflanzenanatomie. Gebrüder Bornträeger. Berlin: Nikolassee.

Niklas, K. J. \& Banks, H. P. 1990. A reevaluation of the Zosterophyllophytina with comments on the origin of lycopods. American Journal of Botany 77, 274-83.

Powell, C. L., Edwards, D. \& Trewin, N. H. 2000. A new vascular plant from the Lower Devonian Windyfield Chert, Rhynie, N.E. Scotland. Transactions of the Royal Society of Edinburgh, Earth Sciences 90 (for 1999), 331-49.

Rayner, R. J. 1983. New observations on Sawdonia ornata from Scotland. Transactions of the Royal Society of Edinburgh: Earth Sciences 74, 79-93.
Rayner, R. J. 1984. New finds of Drepanophycus spinaeformis Göppert from the Lower Devonian of Scotland. Transactions of the Royal Society of Edinburgh: Earth Sciences 75, 353-63.

Remy, W. 1978. Der Dehiszenzmechanismus der Sporangien von Rhynia. Argumenta Palaeobotanica 5, 23-30.

Remy, W., Hass, H. \& Schultka, S. 1986. Anisophyton potoniei nov. spec. aus den Kühlbacher Schichten (Emsian) vom Steinbruch Ufersmühle, Wiehltalsperre. Argumenta Palaeobotanica 7, 12338 .

Remy, W. \& Hass, H. 1996. New information on gametophytes and sporophytes of Aglaophyton major and inferences about possible environmental adaptations. Review of Palaeobotany and Palynology 90, 175-93.

Remy, W. \& Remy, R. 1977. Die Floren des Erdaltertums. Essen: Verlag Glückauf GmbH.

Satterthwait, D. F. \& Schopf, J. W. 1972. Structurally preserved phloem zone tissues in Rhynia. American Journal of Botany 59, 373-6.

Schweitzer, H.-J. 1983. Die Unterdevonflora des Rheinlandes. Palaeontographica B 189, 1-138.

Scott, D. H. 1923. Studies in Fossil Botany, 3rd edn, Vol. II. London: A. \& C. Black Ltd.

Sutton, M. D., Briggs, D. E. G., Siveter, D. J. \& Siveter, D. J. 2001. Methodologies for the visualization and reconstruction of threedimensional fossils from the Silurian Herefordshire lagerstätte. Palaeontologia Electronica 4, Issue 1. [www. document.] URL http://palaeo-electronica.org/2001 1/s2/s2.pdf

Wellman, C. H., Kerp, H. \& Hass, H. 2004. Spores of the Rhynie chert plant Horneophyton lignieri (Kidston \& Lang) Barghoorn \& Darrah, 1938. Transactions of the Royal Society of Edinburgh: Earth Sciences 94 (for 2003), 429-43.

DIANNE EDWARDS, School of Earth, Ocean and Planetary Sciences, Cardiff University, Cardiff CF10 3YE, UK.

MS received 14 December 2003. Accepted for publication 10 June 2004. 